\title{
PENGEMBANGAN MODUL ELEKTRONIK FISIKA BERBASIS KONSTRUKTIVISME UNTUK KELAS X SMA
}

\author{
Sri Maiyena1, Marjoni Imamora', Eza Rahayu Putri' \\ 1Jurusan Tadris Fisika, FTIK IAIN Batusangkar \\ e-mail: srimaiyena@iainbatusangkar.ac.id
}

\begin{abstract}
ABSTRAK
Keterbatasan pada modul cetak serta kurangnya ketersediaan media pembelajaran yang berbasis teknologi menyebabkan kurangnya motivasi siswa dalam mempelajari fisika. Untuk itu perlu dikembangkan sebuah Modul Elektronik fisika berbasis konstruktivisme. Penelitian ini bertujuan untuk menghasilkan Modul Elektronik Fisika yang valid untuk siswa Kelas X SMA. Penelitian ini adalah penelitian pengembangan (research development) dengan menggunakan model 4-D. Pada tahap develop dilakukan pengembangan modul dengan divalidasi oleh 3 orang validator. Berdasarkan hasil validasi terhadap modul elektronik fisika berbasis konstruktivisme yang dikembangkan adalah sangat valid dengan persentase $89,08 \%$.
\end{abstract}

Kata kunci: modul elektronik, materi fisika, kelas X SMA, kontruktivisme, valid

\begin{abstract}
limitations on the hard module and the lack of availability of technology-based learning media led to a lack of student motivation in learning physics. As a result, it is necessary to develop a constructivism-based electronic physucs module. The objective of this research is to know validity of constructivism-based electronic physics module for 1st student in Senior high school. This research is research and development recearch. Feasibility tests of electronic module are carrried out through the validation. Validation was carried out by three validators. Based on validation, it showed that constructivism-based electronic physics module that was developed is very valid with a percentage of $89.08 \%$.
\end{abstract}

Keywords: electronic module, physics learning, 10th grade of Senior High School, constructivisme, valid

DOI: http://dx.doi.org/10.15575/jotalp.v5i1.5739

Received: 21 Agustus 2019 ; Accepted: 14 Januari 2020 ; Published: 29 Februari 2020 


\section{PENDAHULUAN}

Pendidikan memiliki peranan penting dalam proses pembangunan suatu bangsa. Pendidikan merupakan salah satu unsur yang penting untuk menciptakan sumber daya yang mampu mengadakan perubahan bagi bangsa dan negara. Dunia pendidikan diharapkan dapat memberikan sumber daya manusia yang professional untuk memajukan negara dengan ilmu dan teknologinya. Hal ini sebagaimana dinyatakan dalam Undang-Undang dan Peraturan Pemerintah tentang Pendidikan No 20 tahun 2003 Bab 1 Pasal 1, yang menyatakan bahwa pendidikan merupakan usaha yang dilakukan seseorang untuk mengembangkan potensipotensi yang ada dalam dirinya. Potensi meliputi kekuatan spiritual, keagamaan, dan kecerdasan. Semua potensi tersebut diperlukan seseorang untuk mampu menentukan tindakan yang harus dilakukan dalam rangka meraih masa depan untuk kehidupan yang baik (Indonesia, 2003).

Fisika merupakan salah satu cabang dari ilmu pengetahuan yang dapat mengaplikasikan terlaksananya pendidikan. Fisika merupakan ilmu yang mempelajari fenomena dan gejala alam secara empiris, logis sistematis dan rasional yang melibatkan proses dan sikap ilmiah. Dalam pembelajaran fisika, siswa akan dikenalkan tentang materi, konsep, azas, teori, prinsip dan hukum-hukum alam (BSNP, 2006). Siswa juga diajarkan tentang pengetahuan eksperimen di laboratorium dan di alam sebagai proses ilmiah untuk memahami pokok-pokok bahasannya.

Dalam pembelajaran fisika sangat dituntut kemampuan memahami konsep, prinsip maupun hukum-hukum fisika melalui proses berpikir analitis, rasa ingin tahu tinggi dan proses ilmiah. Pembelajaran fisika seharusnya memberikan pengalaman langsung pada siswa dan melibatkannya dalam proses pembelajaran sehingga ia mampu mengkonstruksi dan memahami tentang konsep-konsep dalam pembelajaran fisika. Salah satu pendekatan pembelajaran yang memberikan kesempatan kepada siswa untuk mengkontruksi pemahamannya sendiri adalah pendekatan kontruktivisme. Pembelajaran kontruktivisme adalah pembelajaran yang memerlukan mahasiswa berpartisipasi aktif, kemampuan belajar mandiri, mengembangkan pengetahuan sendiri secara aktif, sedangkan dosen hanya berperan sebagai fasilitator dan mediator dalam proses pembelajaran Metode ini dapat mengembangkan pengetahuan, keterampilan dan sikap positif siswa baik dalam pembelajaran maupun dalam kehidupan sehari-hari (Hamdunah, 2015).

Kenyataan yang ada dilapangan, fisika dianggap sebagai salah satu mata pelajaran yang sulit (Suyoso \& Nurohman, 2014). Hal ini dibuktikan dengan banyaknya siswa yang takut dan tidak menggemari mata pelajaran tersebut. Siswa berpendapat bahwa pembelajaran fisika identik dengan pelajaran yang terdiri dari persamaanpersamaan matematis sehingga menyebabkan suasana yang membosankan.

Disamping itu, kurangnya keterlibatan siswa secara aktif juga menjadi penyebab yang dominan untuk memahami fisika tersebut. Guru dan metode yang dipakai dalam pembelajaran juga mempengaruhi minat siswa dalam belajar fisika. Aplikasi ilmu fisika dalam kehidupan sehari-hari jarang disampaikan oleh guru, guru juga lebih dominan menekankan aspek kognitif saja, sehingga siswa seolah-olah dipaksa menghafal suatu rumus tanpa memahami konsep dalam pembelajaran fisika.

Menjadikan proses pembelajaran fisika menjadi menarik dan disenangi oleh siswa merupakan salah satu tugas guru. Tugas utama guru dalam proses pembelajaran adalah sebagai fasilitator, pengelola dan pembimbing bagaimana membelajarkan siswa. "Dalam era reformasi sekarang ini guru tidak lagi berperan sebagai satu-satunya sumber belajar (learning resources), akan tetapi lebih berperan sebagai pengelola pembelajaran (manager of instruction) sehingga guru dan siswa saling membelajarkan (Sanjaya, 2008). Untuk melaksanakan tugas tersebut guru 
perlu menyediakan berbagai fasilitas dan menciptakan lingkungan belajar yang kondusif sehingga proses pembelajaran berlangsung secara efektif dan efisien.

Salah satu alternatif yang bisa dilakukan oleh guru agar siswa bisa memahami pembelajaran dan proses pembelajaran berlangsung secara efektif dan efesien adalah dengan memberikan siswa bahan ajar. Bahan ajar yang digunakan dalam proses pembelajaran adalah sesuai dengan kurikulum yang berlaku, dan sesuai dengan karakteristik siswa. Disamping itu juga dapat membantu guru dalam menjelaskan materi yang bersifat abstrak.

Berdasarkan wawancara yang dilakukan dengan salah seorang guru fisika di SMA 1 Batipuh, diperoleh informasi bahwa dalam pembelajaran fisika, sebenarnya sudah dibantu dengan media atau sumber belajar berupa buku teks dan LKS. Penggunaan buku paket dan LKS yang ada disekolah sebenarnya merupakan usaha yang sudah baik yang dilakukan guru dalam menggunakan media pembelajaran, tapi penggunaan buku paket dan LKS yang ada belum cukup untuk menambah motivasi siswa untuk mempelajari fisika. Keterbatasan sumber belajar, tampilan yang kurang menarik serta keterbatasan pada indera pandang, juga menjadi kendala siswa dalam memahami pembelajaran fisika. Hal ini menyulitkan siswa untuk membangun pengetahuan mereka dan menerapkan teori atau konsep yang diperoleh dalam menyelesaikan masalah fisika dalam kehidupan sehari-hari.

Sementara itu, berdasarkan wawancara dengan siswa kelas X SMA N 1 Batipuh, didapatkan informasi bahwa penyebab rendahnya motivasi siswa adalah mereka kurang tertarik pada pelajaran fisika karena menurut mereka fisika adalah ilmu yang sulit dan terdiri atas sederetan rumus yang harus dihafal, siswa tidak memahami konsep dari pelajaran fisika, siswa cenderung hanya menghafal rumus dan mengerjakan soalsoal yang diekspresikan dalam bahasa dan simbol- simbol fisika. Konsep yang diterapkan dalam pelajaran fisika jauh dari realitas kehidupan mereka sehari-hari. Pelajaran fisika merupakan pelajaran yang terdiri dari teori dan aplikasinya dalam kehidupan sehari-hari. Akan tetapi dalam praktiknya guru-guru kurang memberikan pengetahuan tentang aplikasinya secara langsung dalam pembelajaran. Mestinya belajar fisika lahir dari rasa ingin tahu tentang fenomena alam berupa fakta, kemudian mereka membangun sebuah konsep. Guru dituntut disamping menanamkan konsep kepada siswa tetapi juga harus melibatkan siswa dalam menemukan konsep itu sendiri. Sehingga mereka dengan mudah membangun pengetahuannya, memahami konsep dan mengaplikasikannya dalam kehidupan seharihari (Bungum, Henriksen, Angell, Tellefsen, \& Bøe, 2015).

Menindak lanjuti kondisi ini, perlu dirancang bahan ajar yang bisa membangun pengetahuan siswa melalui bacaan dan keadaan yang mereka lihat. Dengan menggunakan bahan ajar tersebut, siswa bisa belajar mandiri tanpa ada guru disampingnya. Siswa bisa menemukan sendiri konsep terkait materi yang dipelajarinya. Untuk mewujudkan hal tersebut, dibutuhkan bahan ajar yang bisa membimbing siswa dalam menemukan konsep terkait materi yang dipelajarinya. Salah satu bahan ajar yang meliputi serangkaian pengalaman belajar terencana disusun secara sistematis, dan terarah untuk membantu siswa menguasai tujuan pembelajaran yang spesifik adalah modul (Perdana, Sarwanto, \& Sukarmin, 2017). "Modul merupakan suatu paket kurikulum yang disediakan untuk belajar sendiri, tanpa guru siswa dapat belajar sendiri (Sabri, 2010).

Modul sebagai salah satu media pembelajaran yang adaptif terhadap perkembangan teknologi yang juga dengan baik membelajarkan siswa secara mandiri, merupakan media pembelajaran yang cocok digunakan sekarang ini. Ditengah perkembangan teknologi informasi dan komunikasi saat ini, dimana pembelajaran berbasis elektronik sudah menjadi bagian integral dalam dunia pendidikan. Salah satu yang 
paling efektif adalah penggunaan modul elektronik (Getuno, Kiboss, Changeiywo, \& Ogola, 2015).

Penggunaan sumber belajar elektronik sebagai media pembelajaran telah dibuktikan secara meyakinkan melalui beberapa penelitian. Arkorful \& Abaidoo, 2014 telah melakukan penelitian tentang peran e-learning, kelebihan dan kekurangannya dengan mengadopsinya untuk perguruan tinggi. Hasil penelitian menunjukkan bahwa adopsi terhadap e-learning pada beberapa institusi telah meningkatkan akses fakultas dan mahasiswa untuk mendapatkan informasi dan telah menyediakan lingkungan yang kaya untuk kolaborasi diantara para mahasiswa untuk meningkatkan standar akademik. Berdasarkan review literatur secara keseluruhan yang menjelaskan keuntungan dan kerugian dari elearning menunjukkan perlunya implementasi dalam pendidikan tinggi untuk fakultas, administrator dan mahasiswa untuk menikmati manfaat penuh yang datang dengan adopsi dan implementasinya.

Penelitian yang dilakukan oleh Santosa, Santyadiputra, \& Divayana, 2017, menunjukkan bahwa penggunaan modul eletronik mampu memotivasi siswa serta meningkatkan kemandirian siswa. Hapsari \& Widodo, 2016, melaporkan hasil penelitiannya bahwa penggunaan bahan ajar berbasis konstruktivismetakognitif efektif untuk meningkatkan pengetahuan dan keterampilan metakognisi siswa rerata meningkatkan pengetahuan dan keterampilan metakognisi siswa.

Sufiyah \& Sumarsono, 2015, juga telah melakukan penelitian tentang pengembangan media pembelajaran modul elektronik interaktif pada mata pelajaran ekonomi untuk kelas X lintas minat ekonomi SMA Laboratorium UM kota Malang. Hasil penelitian menunjukkan bahwa media pembelajaran modul elektronik interaktif yang dikembangkan mampu meningkatkan nilai ekonomi siswa kelas X lintas minat ekonomi SMA Laboratorium.
Disamping itu, Abou El-Seoud et al., 2014 juga telah melakukan penelitian tentang e-learning dan motivasi mahasiswa, studi penelitian mengenai akibat dari e-learning pada pendidikan tinggi. Berdasarkan hasil penelitian diperoleh bahwa penggunaan fitur interaktif dari e-learning dapat meningkatkan motivasi mahasiswa dalam proses pembelajaran.

Modul elektronik fisika yang akan dikembangkan adalah modul elektronik dengan pendekatan konstruktivisme. Modul elektronik fisika dengan pendekatan kontruktivisme merupakan modul dengan pendekatan yang menekankan pentingnya siswa membangun sendiri pengetahuan mereka lewat keterlibatan aktif dalam proses pembelajaran, meningkatkan minat, konsentrasi, keterampilan dalam berpikir kritis dan kreatif (Matanluk, Mohammad, Norizah, Kiflee, \& Imbug, 2013). Tujuan dari penelitian ini adalah untuk mengetahui validitas modul elektronik fisika berbasis kontruktivisme untuk kelas X SMA pada materi pokok suhu dan kalor.

\section{METODE PENELITIAN}

Penelitian ini adalah penelitian pengembangan yaitu mengembangkan Modul elektronik fisika berbasis konstruktivisme untuk kelas X SMA pada materi pokok suhu dan kalor. Rancangan penelitian ini menggunakan model 4-D (Trianto, 2010). Namun dibatasi sampai pada tahap develop yaitu diperoleh modul elektronik berbasis konstruktivisme yang valid. Untuk lebih jelasnya terdapat pada gambar 1 . 


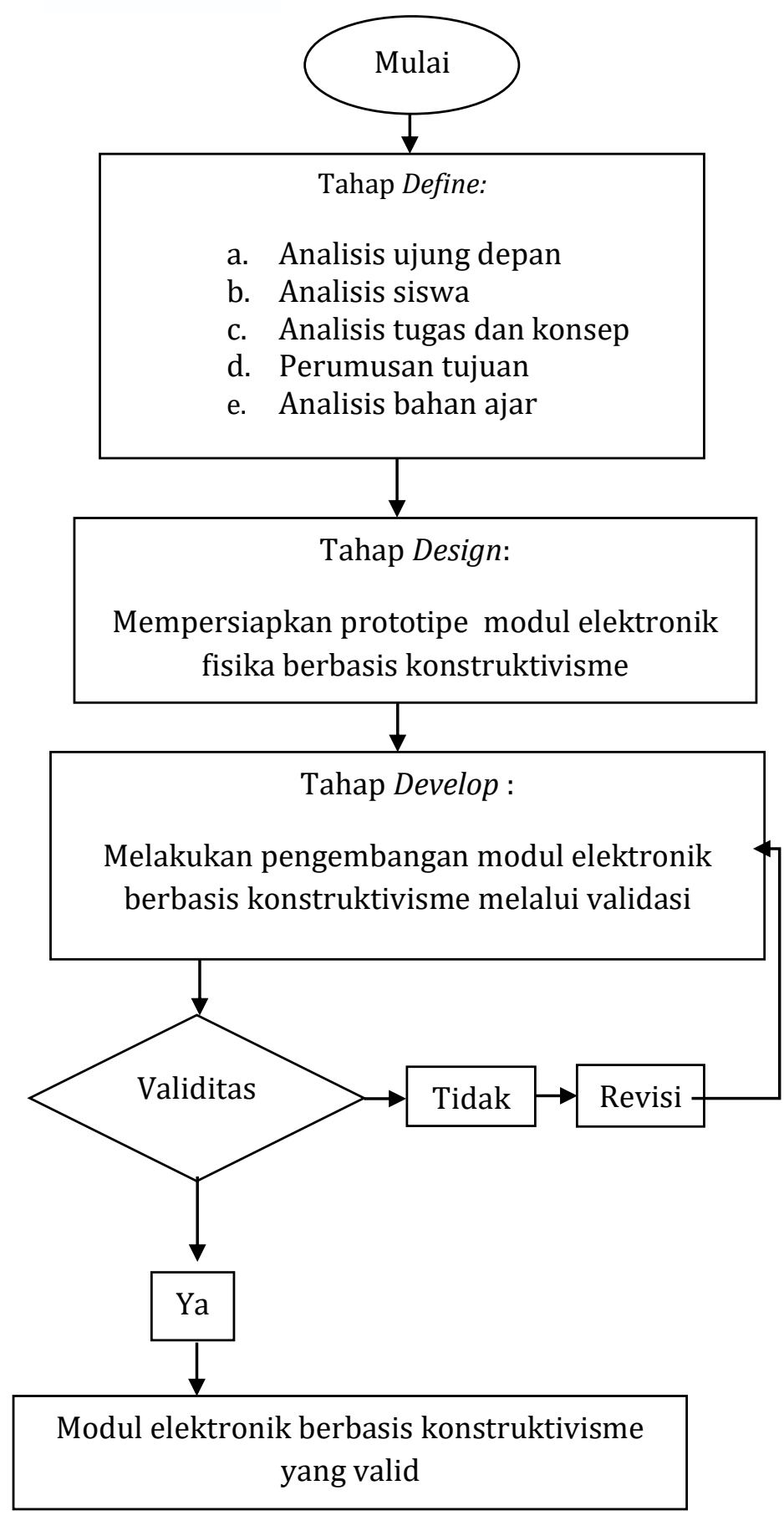

Gambar 1. Rancangan Penelitian

Pada tahap define dilakukan untuk melihat gambaran mengenai bahan ajar yang digunakan di sekolah. Analisis ini dilakukan dengan melakukan wawancara dengan guru fisika kelas X SMA. Analisis siswa dilakukan untuk melihat kebutuhan serta karakteristik siswa yang meliputi kemampuan, motivasi, kebiasaan serta cara belajar siswa, sedangkan pada analisis tugas dan konsep bertujuan untuk mengetahui konsepkonsep penting pada materi suhu dan kalor serta tugas-tugas penunjang yang harus ada dalam sebuah modul yang akan dikembangkan. Perumusan tujuan pembelajaran dilakukan untuk menentukan rumusan tujuan pembelajaran, dimulai dengan menganalisis silabus pembelajaran fisika kelas $\mathrm{X}$ semester II. Menganalisis bahan ajar adalah menganalisis bahan ajar fisika Kelas X Semester II yang dipakai oleh guru fisika sebagai sumber belajar siswa. Sebelum merancang modul, buku teks fisika kelas $\mathrm{X}$ semester II sudah di telaah terlebih dahulu.

Rancangan prototype modul elektronik fisika berbasis konstruktivisme dirancang sesuai dengan standar kompetensi, kompetensi dasar dan indikator yang telah ditetapkan, mengumpulkan bahan pembuatan modul elektronik dan programing.

Pada tahap pengembangan (develop), dilakukan validasi oleh pakar. Validasi dilakukan menggunakan lembar validasi dan diskusi. Dimana lembar tersebut direvisi oleh pakarnya sampai modul elektronik yang dikembangkan valid. Validasi yang akan dilakukan meliputi validasi isi dan konstruk. Validasi isi berisi item item yang menunjukkan kesesuaian antara isi produk dan tujuan pembelajaran. Validasi konstruk berisi item item yang menunjukkan kesesuaian produk yang dihasilkan dengan unsur-unsur pengembangan yang telah ditetapkan. Aspek-aspek yang akan divalidasikan dapat dilihat pada tabel 1. 
Tabel 1. Validasi modul elektronik fisika berbasis konstruktivisme

\begin{tabular}{cccc}
\hline No & Aspek & $\begin{array}{c}\text { Metode } \\
\text { Pengumpulan } \\
\text { Data }\end{array}$ & Instrumen \\
\hline 1 & Tujuan & & \\
2 & Rasional & & Lembar \\
3 & Isi modul & Validator & validasi \\
4 & Karakteristik & Kalian & \\
5 & Kesesuaian & & \\
& bahasa & & \\
6 & Bentuk fisik & & \\
\cline { 2 - 4 }
\end{tabular}

Setelah modul elektronik tersebut divalidasi oleh beberapa orang validator, selanjutnya data tersebut ditabulasi. Hasil tabulasi selanjutnya dicari presentasenya dengan rumus:

$$
\mathrm{P}=\frac{\text { jumlah } \text { skor per item }}{\text { skor maksimal }} \times 100 \%
$$

Berdasarkan persentase yang diperoleh, selanjutnya dikategorikan berdasarkan tabel 2 .

Tabel 2. Kategori validitas modul

\begin{tabular}{cc}
\hline $\mathbf{( \% )}$ & Kategori \\
\hline $0-20$ & Tidak Valid \\
\hline $21-40$ & Kurang Valid \\
\hline $41-60$ & Cukup Valid \\
\hline $61-80$ & Valid \\
\hline $81-100$ & Sangat Valid \\
\hline
\end{tabular}

\section{HASIL DAN PEMBAHASAN}

\section{Tahap define (pendefinisian)}

Tahap ini dimulai dengan analisis ujung depan, analisis siswa, analisis konsep dan tugas, perumusan tujuan pembelajaran dan analisis bahan ajar. Hasil analisis ujung depan dilakukan dengan mewawancarai guru fisika SMA kelas X. Berdasarkan hasil wawancara diperoleh informasi bahwa materi suhu dan kalor merupakan materi yang sangat dekat dengan kehidupan siswa, sehingga akan lebih baik dengan menampilkan peristiwa-peristiwa pada materi tersebut yang berkaitan dengan kehidupan sehari-hari dan bisa membuat siswa untuk membangun suatu konsep tentang materi yang dipelajari. Hal ini seperti diungkapkan oleh Ornstein dan Hunkins (1993) bahwa pembelajaran terjadi ketika siswa berinteraksi dengan lingkungan, belajar tetap berlangsung di kelas seperti biasanya (Petchtone, 2014). Namun, dalam penyajian materi suhu dan kalor pada bahan ajar yang telah tersedia kurang menarik, bahasa yang digunakan kurang komonikatif dan sulit untuk dipahami siswa. Kurangnya bahan ajar disekolah juga membuat guru kesulitan dalam menjelaskan materi, karena hanya mengharapkan materi yang akan disampaikan guru tanpa ada usaha dari dirinya sendiri untuk mempelajari materi suhu dan kalor yang akan dipelajari itu. Hal ini menyebabkan guru menghabiskan banyak waktu untuk menjelaskan materi suhu dan kalor kepada siswa.

Dalam pembelajaran fisika, penggunaan buku paket sebagai sumber belajar dan media sangat membantu guru dalam menyampaikan materi pelajaran. Namun, keterbatasan buku paket dan sumber belajar lainya menjadi kendala dalam pembelajaran fisika di sekolah tersebut. Disisi lain guru juga sering menggunakan buku yang berbeda, sehingga siswa yang mempunyai tingkat kepintaran yang rendah akan sulit memahami materi yang terdapat di dalam buku paket tersebut. Di samping itu kegiatan pembelajaran juga masih berlangsung satu arah, dimana guru menjelaskan materi pelajaran, memberikan contoh dan siswa disuruh mengerjakan latihan. Ketika proses pembelajaran berlangsung, hanya sebagian kecil siswa yang mengerti sedangkan sebagian besar lainnya tidak mengerti. Hal ini disebabkan, kurangnya interaktif atau keterlibatan siswa secara langsung dalam pembelajaran.

Untuk menutupi keterbatasan tersebut hendaknya seorang guru mampu mencarikan solusi atau jalan keluar yang sesuai dengan kebutuhan siswa dalam mempelajari fisika khususnya materi suhu dan kalor. Guru harus dapat membantu menginformasikan pengajaran dan mengingatkan 
siswa bahwa siswalah yang berada pada pusat pedagogi (Alsharif, 2014). Bahan ajar perlu dikembangkan dan diorganisasikan agar pembelajaran tercapai secara efektif dan efisien sehingga menghasilkan nilai yang memuaskan. Untuk itu, pengembangan modul yang dirancang adalah pengembangan modul elektronik fisika berbasis konstruktivisme pada materi suhu dan kalor. Melalui modul ini diharapkan siswa menjadi berminat dan tidak hanya menerima penjelasan dari guru namun siswa juga dapat belajar secara aktif dan dapat belajar secara mandiri maupun berkelompok (Auditor \& Naval, 2014). Disamping itu siswa juga diharapkan dapat menerapkan apa yang telah mereka pelajari dalam situasi baru, yang tidak hanya mampu menemukan masalah tetapi juga menyelesaikannya secara efektif (Serafín, Dostál, \& Havelka, 2015).

Analisis siswa dilakukan untuk melihat karakteristik siswa yang meliputi kemampuan berpikir dan motivasi belajar. Hasil analisa yang dilakukan pada siswa kelas X SMA N 1 Batipuh menunjukan bahwa dalam proses pembelajaran siswa cendrung pasif, pembelajaran masih berpusat pada guru dan keterbatasan sumber belajar.

Berdasarkan pertimbangan diatas, maka kegiatan pembelajaran harus membuat siswa aktif dalam belajar dan mampu membangun sebuah konsep dari apa yang mereka pelajari ((Pinilih \& Masykuri, 2016). Untuk mendukung hal tersebut perlu dikembangkan sebuah bahan ajar berupa modul elektronik berbasis konstruktivisme pada materi suhu dan kalor.

Analisis tugas dan konsep dilakukan dengan cara mereview literatur tentang modul elektronik yang akan dikembangkan. Pengetahuan akan bahan ajar yang akan dikembangkan adalah salah satu syarat untuk mengembangkannya. Modul elektronik adalah bahan belajar mandiri yang disusun secara sistematis sampai kebagian terkecil yang dipakai dalam pembelajaran, yang dalam penggunaannya memakai piranti elektronik berupa komputer untuk meningkatkan daya interaktif siswa dan ketertarikan siswa sehingga tujuan dari pembelajaran tersebut dapat dicapai dengan baik (Gaikwad \& Tankhiwale, 2014).

Review literatur tentang modul elektronik bertujuan untuk mengetahui format pengembangan modul elektronik fisika pada materi suhu dan kalor dan dapat dirancang semenarik mungkin. Modul elektronik harus dapat dipelajari siswa secara sendiri, modul elektronik dapat memberikan pengaruh dalam proses pembelajaran siswa (Rufii, 2015).

Dalam pengembangan bahan ajar dan perumusan tujuan pembelajaran, silabus merupakan salah satu perangkat pembelajaran yang harus diperhatikan. Hal ini bertujuan agar bahan ajar yang dikembangkan sesuai dengan tuntutan dan kebutuhan terhadap siswa. Berdasarkan silabus mata pelajaran fisika kelas X semester II, materi yang harus diberikan terdiri dari 4 standar kompetensi, yaitu: 1) Menerapkan prinsip kerja alat alat optik; 2) Menerapkan konsep kalor dan prinsip konservasi energi pada berbagai perubahan energi; 3) Menerapkan konsep kelistrikan dalam berbagai penyelesaian masalah dan berbagai produk teknologi; 4) Memahami konsep dan prinsip gelombang eletromagnetik.

Berdasarkan analisis silabus pembelajaran, maka modul dirancang untuk standar kompetensi yang kedua yang terdiri dari 3 kompetensi dasar yaitu: 1) Menganalisis pengaruh kalor terhadap suatu zat; 2) Menganalisis cara perpindahan kalor; 3) Menerapkan asas Black dalam pemecahan masalah.

Dalam mengembangkan bahan ajar, ketersedian bahan ajar merupakan suatu hal yang perlu diperhatikan. Hal ini betujuan agar bahan ajar yang dikembangkan dapat menutupi kekurangan yang terdapat dalam bahan ajar yang telah ada. Sumber belajar yang tersedia diantaranya adalah buku teks dan LKS. Minimnya unsur interaktif yang terdapat didalam LKS dan buku teks menyebabkan kurangnya minat siswa untuk belajar. Selain itu, ketersedian buku teks dengan karangan yang berbeda, serta jumlah buku teks yang tidak 
sebanding dengan jumlah siswa juga menjadi kendala dalam belajar.

LKS yang digunakan dibuat oleh guru, kemudian pada saat pembelajaran berlangsung siswa disuruh memperbanyak LKS tersebut, sehingga pembelajaran menjadi kurang efektif. Sumber belajar yang digunakan masih memiliki keterbatasan pada indra pandang siswa karena untuk audio dan visual sulit digunakan. Materi suhu dan kalor yang ditampilkan pada bahan ajar yang tersedia tidak menampilkan masalah-masalah yang berkaitan dengan kehidupan sehari-hari siswa sehingga siswa sulit untuk membangun sebuah konsep tentang materi tersebut.

Pada materi suhu dan kalor seharusnya, banyak komponen yang bisa dikaitkan dengan kehidupan sehari-hari siswa sehingga siswa bisa menemukan solusi dan membangun sebuah konsep untuk materi suhu dan kalor. Namun pada bahan ajar yang tersedia berisi pengetahuan secara umum. Oleh sebab itu dilakukan pengembangan modul elektronik fisika berbasis konstruktivisme untuk materi suhu dan kalor agar bisa membantu siswa mempelajari materi suhu dan kalor secara efektif dan efesien.

\section{Tahap design (perancangan)}

Modul elekronik fisika berbasis konstruktivisme dirancang dan dikembangkan untuk materi suhu dan kalor. Pada bagian materi dimulai dengan permasalahan yang dekat dengan keseharian siswa, mereka dipandu untuk membangun pengetahuannya dan menemukan konsep sendiri tentang materi yang dipelajari. Modul ini disajikan dengan langkah-langkah konstruktivisme yang meliputi fase stars, fase eksplorasi, fase refleksi, serta fase aplikasi dan diskusi. Produk dibuat dengan menggunakan microsoft word yang selanjutnya disimpan dalam format PDF.

Kemudian file modul dikembangkan dalam software 3D pageflip Profesional dengan format exe, dimana dapat dibuka secara langsung tanpa melalui software khusus. Perancangan modul ini menggunakan beberapa software diantaranya adalah: 1) Macromedia Flash, dalam perancangan modul elektronik fisika software ini digunakan untuk membuat contoh soal, latihan (asah otak) dan evaluasi dengan penilaian secara otomatis (gambar 2); 2) Movie maker dan format factory, dalam perancangan modul elektronik fisika software format factory (gambar 3) digunakan untuk mengedit video yang didownload sedangkan movie maker digunakan untuk membuat sebuah video pembelajaran (gambar 4); 3) 3D pageflip profesional, software ini digunakan pada tahap akhir pembuatan modul elektronik (gambar 5).

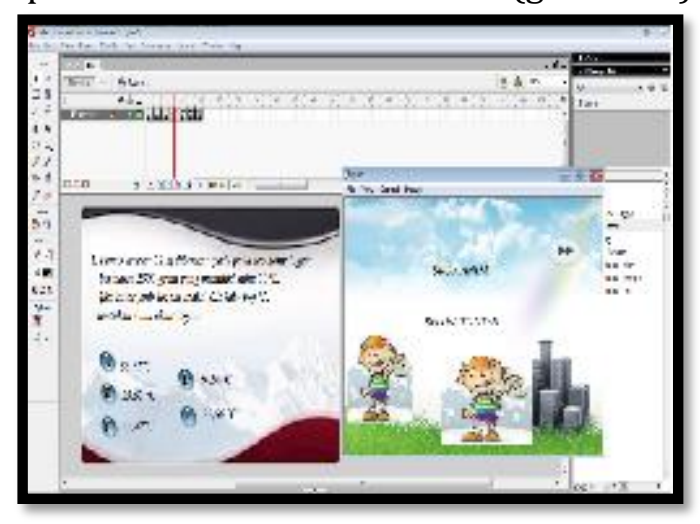

Gambar 2. Tampilan soal menggunakan macromedia flash

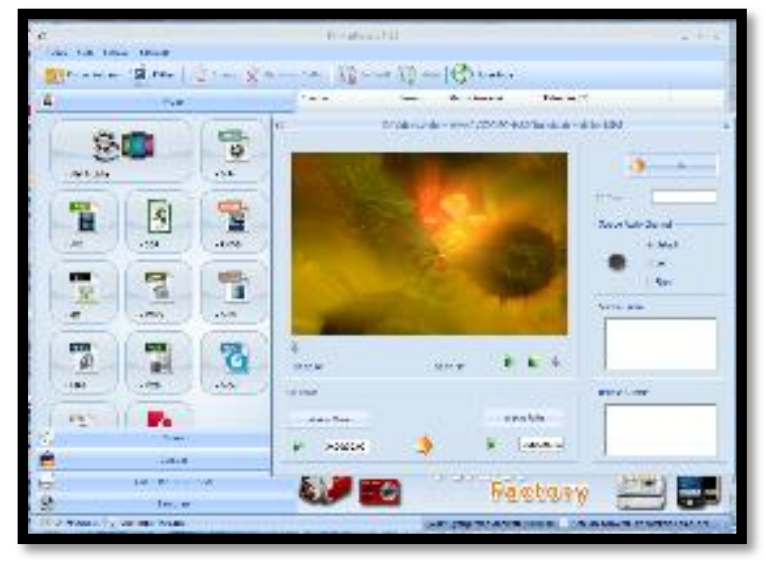

Gambar 3. Tampilan saat mengedit video menggunakan format factory 


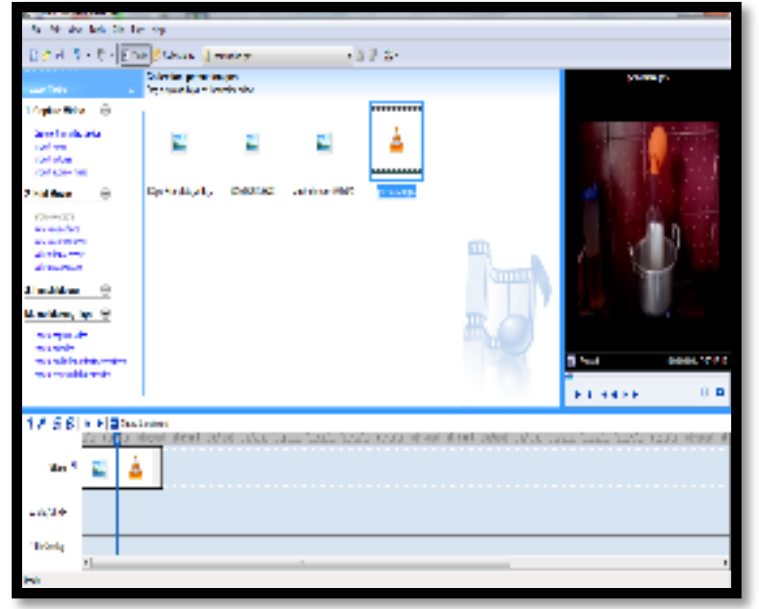

Gambar 4. Tampilan saat membuat video dengan menggunakan movie maker

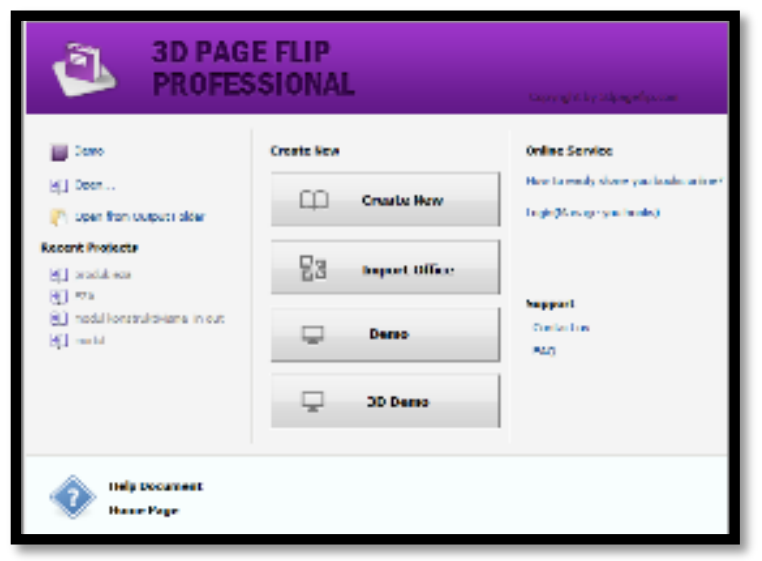

Gambar 5. Tampilan aplikasi 3D Pageflip Profesional

Adapun tampilan akhir modul menggunakan $3 D$ Pageflip profesional yaitu: 1) Halaman cover modul elektronik didesain menggunakan program Microsoft Office Publisher 2007. Tampilan cover dibuat semenarik mungkin dengan warna yang cerah sehingga siswa tertarik untuk membaca modul tersebut. Halaman cover dirancang menggunakan warna hijau yang didukung dengan gambar dan judul tentang suhu dan kalor (gambar 6); 2) Pada halaman selanjutnya terdapat halaman kata pengantar (gambar 7), daftar isi (gambar 8), petunjuk penggunaan icon pada modul (gambar 9), petunjuk penggunaan modul secara umum, serta peta konsep. Peta konsep sebagai bahan acuan bagi siswa, menyusun kerangka berfikir untuk membangun pengetahuan awal siswa. Tampilan daftar isi menggunakan link supaya mempermudah siswa untuk membaca modul. Link tersebut disesuaikan dengan halaman pada modul; 3) Selanjutnya pada modul elektronik ini terdapat 4 sub topik, pada setiap sub topik diawali dengan gambar yang berhubungan dengan materi yang akan dipelajari (gambar 10). Ini bertujuan untuk membuat ketertarikan siswa mempelajari materi tersebut. Pada bagian pendahuluan masing-masing materi terdapat standar kompetensi, indikator dan tujuan pembelajaran yang menjadi pedoman bagi siswa untuk mempelajari materi tersebut (gambar 11); 4) Pada halaman materi disajikan dengan langkah konstruktivisme yang terdiri dari fase start (gambar 12), pada fase ini terdapat cuplikan video pembelajaran yang berhubungan dengan materi yang akan dipelajari (gambar 13). Dalam video tersebut terdapat beberapa permasalahan yang berkaitan dengan kehidupan sehari-hari siswa. Tampilan video ini bertujuan untuk mempermudah siswa mengkonstruksi dan menemukan konsep yang berkaitan dengan topik pelajaran. Tampilan video dibuat dua pilihan (gambar 14). Selanjutnya, fase ekplorasi (gambar 15), pada fase ini terdapat uraian materi untuk menjawab beberapa permasalahan yang ada pada fase start. Selanjutnya fase refleksi yang berisi contoh soal dan fenomena fisika yang berhubungan dengan materi tersebut (gambar 16). Terakhir, Fase aplikasi dan diskusi yang berisi latihan soal untuk mengukur pemahaman siswa terhadap materi (gambar 17); 5) Halaman selanjutnya adalah halaman evaluasi dan halaman kesimpulan (gambar 18). Halaman evaluasi berisikan 20 soal yang mencakup semua 
materi yang ada dalam modul elektronik; 6) Modul elektronik dikembangkan dengan beberapa tombol seperti tombol kembali ke halaman daftar isi, tombol kembali ke materi (fase eksplorasi), tombol yang digunakan untuk melihat kolom contoh soal, tombol ini digunakan untuk melihat kolom latihan soal, tombol untuk melihat kolom evaluasi, tombol yang digunakan untuk melihat beberapa gambar yang berkaitan dengan materi

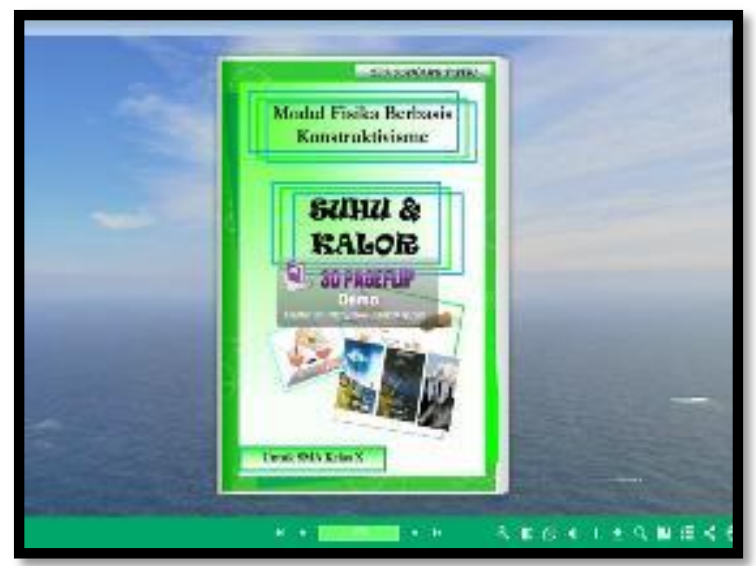

Gambar 6. Tampilan cover modul elektronik menggunakan 3D pageflip Profesional

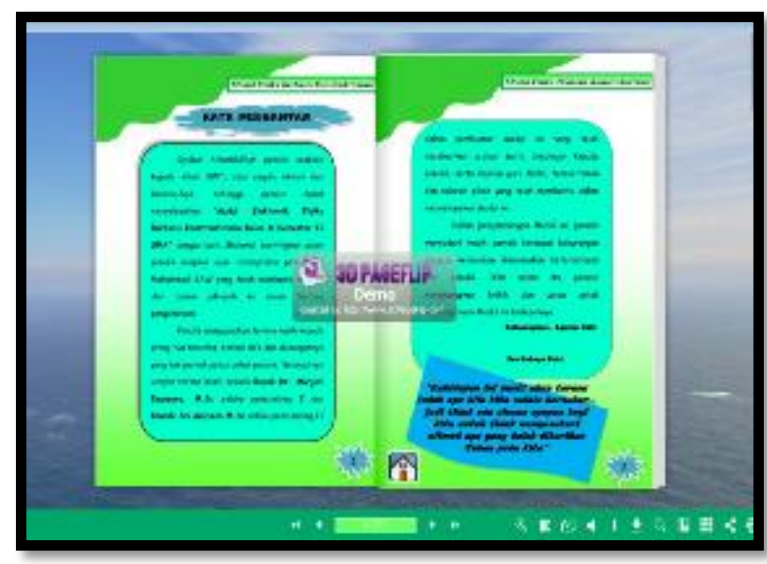

Gambar 7. Tampilan kata pengantar

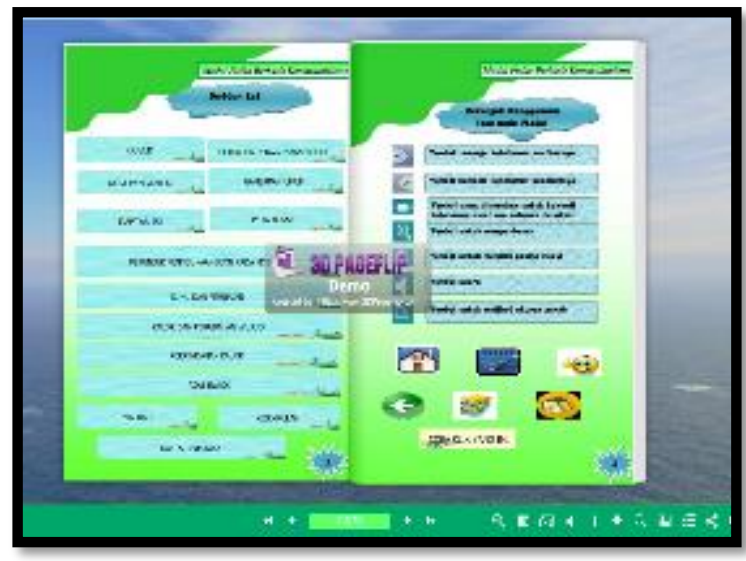

Gambar 8. Tampilan daftar isi dan petunjuk penggunaan icon pada modul

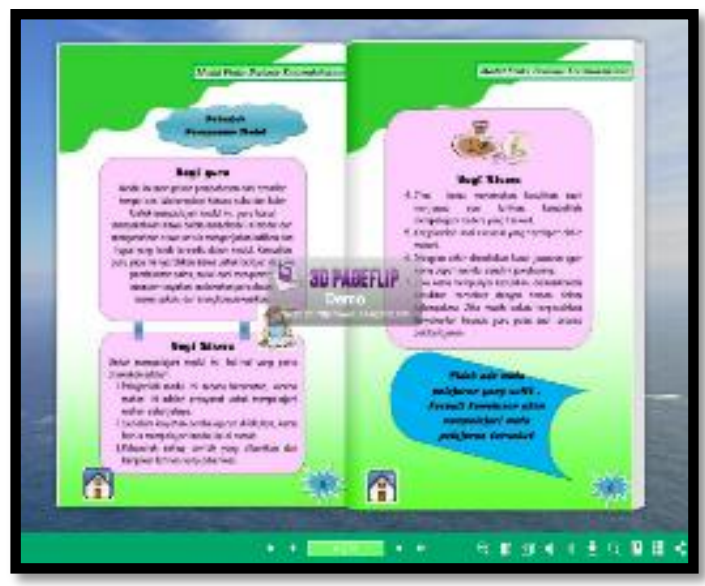

Gambar 9. Tampilan petunjuk penggunaan modul

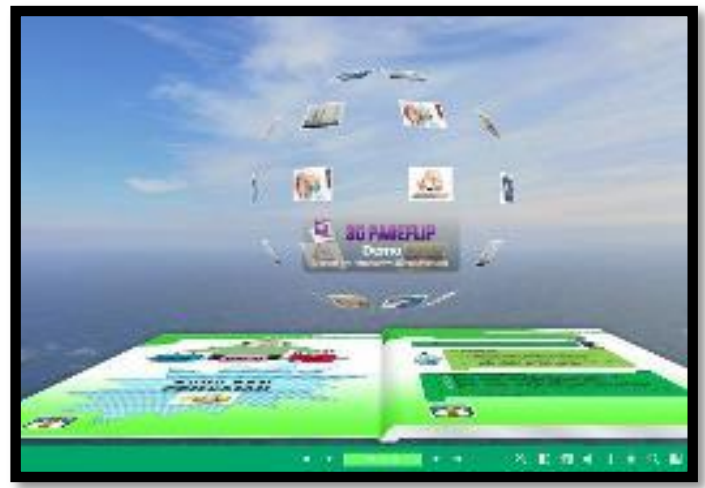


Gambar 10. Tampilan halaman depan materi dengan menggunakan 3D pageflip Profesional

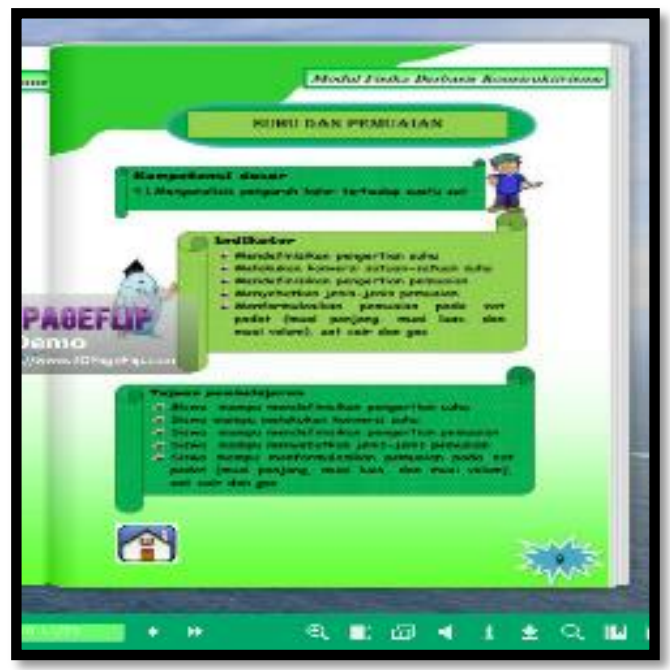

Gambar 11. Tampilan KD, indikator dan tujuan pembelajaran menggunakan $3 D$ pageflip Profesional

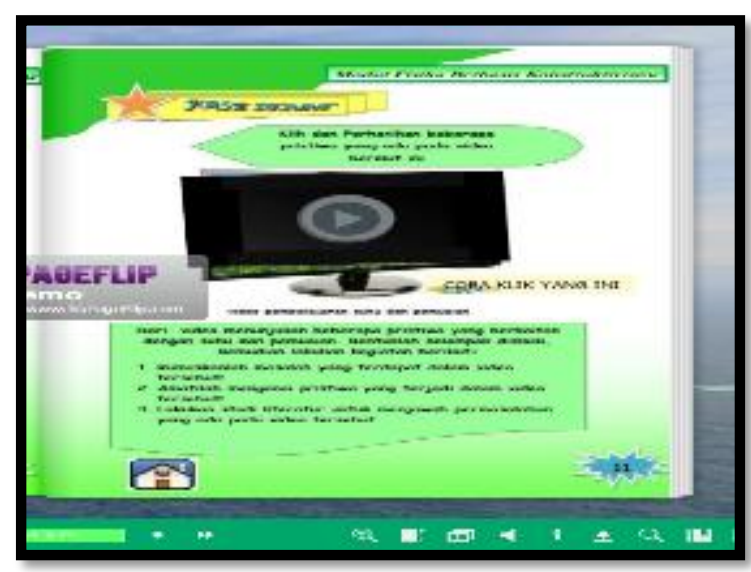

Gambar 12. Tampilan fase start dengan menggunakan 3D Pageflip Profesional

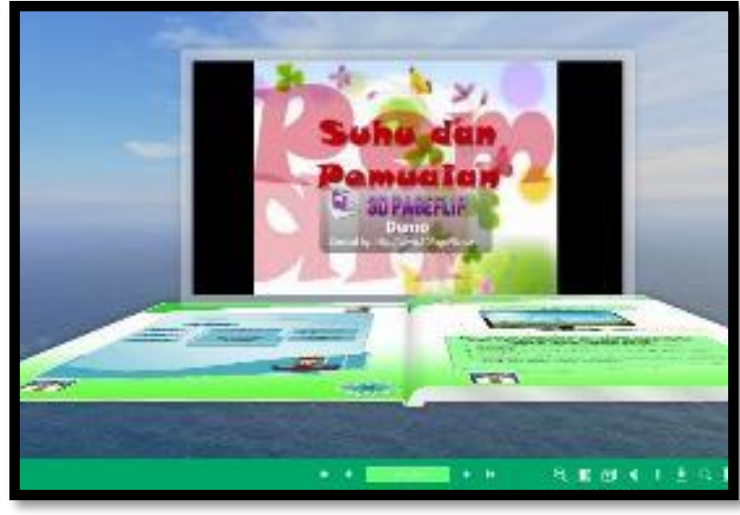

Gambar 13. Tampilan video pada fase start menggunakan 3D Pageflip Profesional

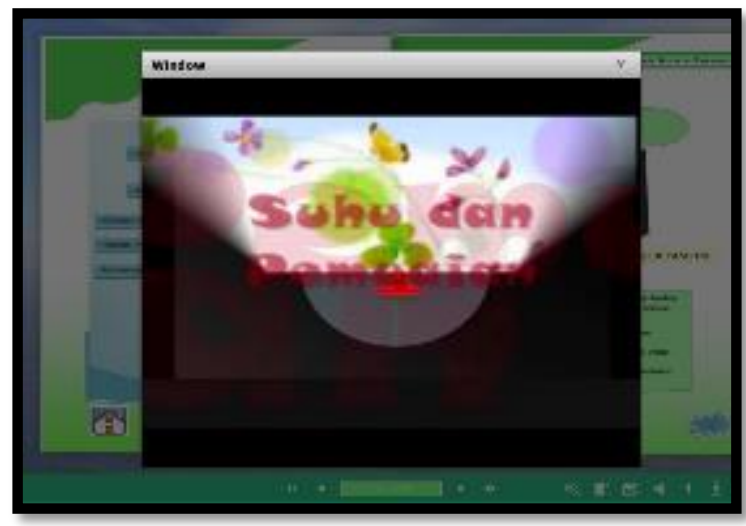

Gambar 14. Tampilan lain video pada fase start menggunakan 3D Pageflip Profesional

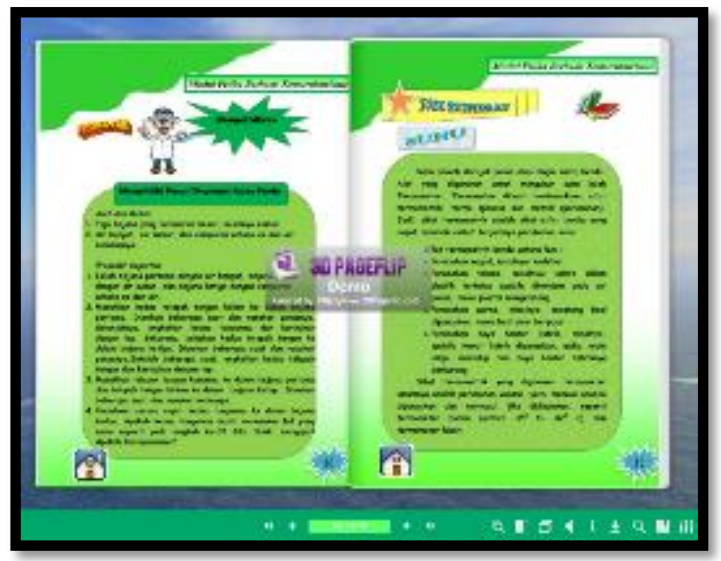

Gambar 15. Tampilan tahap Eksplorasi 


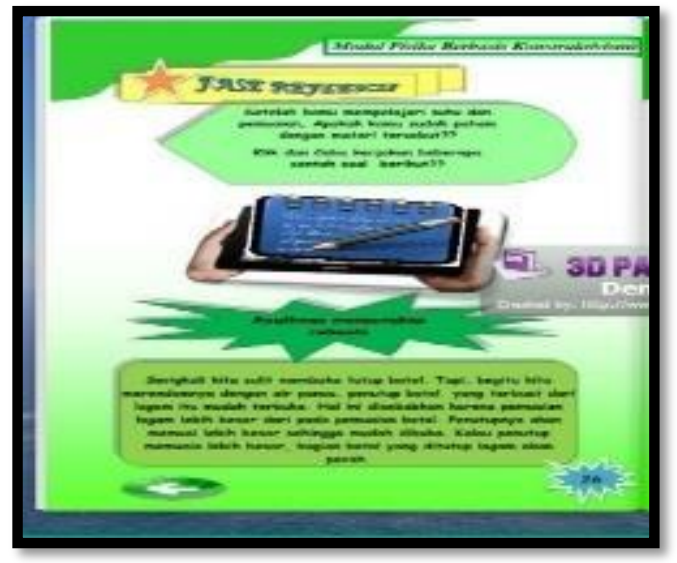

Gambar 16. Tampilan tahap refleksi

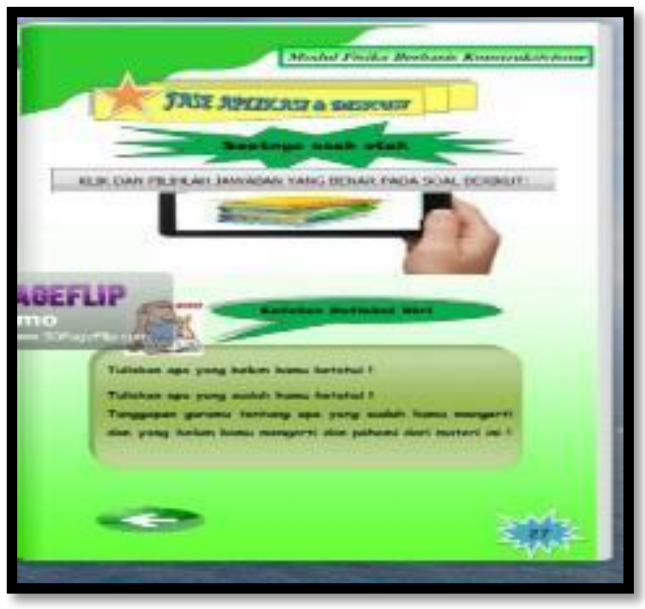

Gambar 17. Tampilan fase aplikasi dan diskusi

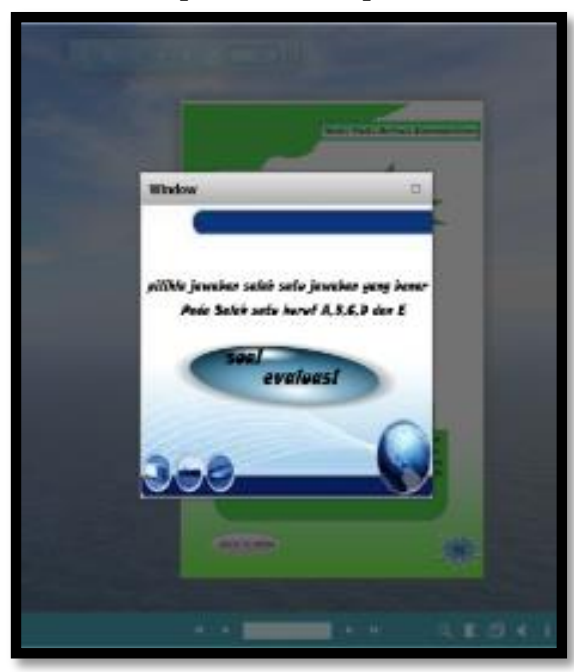

Gambar 18. Tampilan halaman evaluasi menggunakan 3D pageflip Profesional

\section{Tahap develop (pengembangan)}

Sub Bab 3 (Cambria 11, ditebalkan).

Modul elektronik fisika yang telah dikembangkan divalidasi oleh beberapa orang validator. Validasi dilakukan dengan menggunakan instrumen validasi, saran-saran dan komentar dari validator dijadikan pertimbangan untuk perbaikan modul elektronik yang telah dirancang sehingga dihasilkan sebuah modul elektronik yang valid. Data hasil validasi modul elektronik fisika berbasis konstruktivisme dapat dilihat pada tabel 3.

Tabel 3. Data hasil validasi modul elektronik fisika berbasis konstruktivisme

\begin{tabular}{|c|c|c|c|c|c|c|c|c|}
\hline \multirow[b]{2}{*}{ No } & \multirow{2}{*}{$\begin{array}{c}\text { Aspek } \\
\text { Yang } \\
\text { dinilai }\end{array}$} & \multicolumn{3}{|c|}{ Validator } & \multirow[b]{2}{*}{ Jml } & \multirow[b]{2}{*}{$\begin{array}{l}\text { Skor- } \\
\text { Maks }\end{array}$} & \multirow[b]{2}{*}{$\%$} & \multirow[b]{2}{*}{ Ket } \\
\hline & & 1 & 2 & 3 & & & & \\
\hline 1 & Tujuan & 9 & 12 & 11 & 32 & 36 & 88,9 & $\begin{array}{c}\text { Sangat } \\
\text { Valid }\end{array}$ \\
\hline 2 & Rasional & 6 & 8 & 7 & 21 & 24 & 87,5 & $\begin{array}{c}\text { Sangat } \\
\text { Valid }\end{array}$ \\
\hline 3 & Isi modul & 19 & 21 & 23 & 63 & 72 & 87,5 & $\begin{array}{c}\text { Sangat } \\
\text { Valid }\end{array}$ \\
\hline 4 & $\begin{array}{c}\text { Karakterist } \\
\text { ik }\end{array}$ & 21 & 24 & 23 & 68 & 72 & 94,4 & $\begin{array}{c}\text { Sangat } \\
\text { Valid }\end{array}$ \\
\hline
\end{tabular}

Kesesuaian

$\begin{array}{lllllllll}5 & \text { bahasa } & 20 & 27 & 24 & 71 & 84 & 84,5 & \text { Valid }\end{array}$

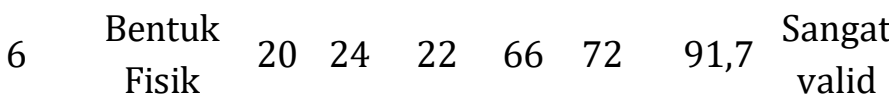

$\begin{array}{cccccccc}\text { Jumlah } & 95 & 116 & 110 & 321 & 360 & 89,0 & \text { Sangat } \\ 8 & \text { Valid }\end{array}$

Tabel 3 menunjukkan bahwa hasil validasi modul elektronik fisika berbasis konstruktivisme. Setiap aspek berkisar antara 87,5 \% hingga $91,7 \%$. Secara keseluruhan rata rata modul elektronik fisika berbasis konstruktivisme 
tergolong sangat valid dengan persentase 89,08 $\%$. Dengan demikian pertanyan penelitian "Bagaimana validitas modul elektronik fisika berbasis konstruktivisme kelas X SMA pada materi pokok suhu dan kalor" telah terjawab. Berdasarkan deskripsi dari hasil validasi menunjukan bahwa modul elektonik fisika yang peneliti rancang sudah valid dengan melakukan perbaikan-perbaikan sesuai saran validator.

Adapun revisi yang telah dilakukan sesuai saran dan masukan dari validator adalah: 1) Memperbaiki tujuan pembelajaran; 2) Memberikan arahan/perintah pada saat penyelidikan; 3) Memperhatikan dan memperbaiki penulisan modul, masih terdapat kesalahan dalam pengetikan. Semua saran dan masukan dari validator, sudah dilaksanakan dalam perbaikan modul elektronik fisika berbasis konstruktivisme.

Berdasarkan tabel 3, aspek tujuan pembelajaran yang terdapat di dalam modul elektronik dapat dinyatakan bahwa kompetensi inti dan kompetensi dasar dalam modul elektronik sudah dinyatakan dengan jelas, indikator pembelajaran sudah mampu mengukur kompetensi siswa, tujuan pembelajaran yang akan dicapai sudah jelas dan sesuai dengan indikator pembelajaran. Tujuan yang diharapkan didalam modul telah sesuai dengan silabus yang telah dianalisis. Hal ini sebagaimana yang telah dikembangkan oleh (Winkel, 1996) bahwa materi pelajaran harus relevan dengan tujuan yang hendak dicapai, materi pelajaran harus sesuai dengan taraf kesulitan dan kemampuan siswa, materi pelajaran harus dapat menunjang motivasi siswa, materi pelajaran harus dapat membantu siswa untuk terlibat aktif dan harus sesuai dengan prosedur serta sesuai dengan media yang tersedia.

Pada aspek rasional modul elektronik, dapat dinyatakan bahwa modul sesuai dengan tujuan yang telah dirumuskan dan dapat mengukur kemampuan siswa, dapat mengembangkan keterampilan siswa seperti kemandirian, tanggung jawab untuk hasil belajar dan kemampuan untuk umpan balik (Shurygin \& Sabirova, 2017). Disamping itu juga berisi informasi tentang kebermaknaan modul elektronik untuk perkembangan akademik siswa.

Pada aspek isi modul elektronik, dapat dinyatakan bahwa judul dan kompetensi inti sudah dinyatakan dengan jelas. Tugas dan latihan yang terdapat pada modul sudah dapat mengukur kemampuan siswa, dan perkembangan belajarnya. Penyajian materi pada modul elektronik menggunakan video pembelajaran sudah dapat menunjang pemahaman materi pembelajaran, lembar kerja yang mampu memeriksa hasil kerja siswa secara otomatis, dan tampilan fisik modul yang ditunjang dengan warna dan gambar-gambar yang menarik. Semua bagian tersebut sudah terdapat didalam modul elektronik. Penyajian modulnya sudah terencana, tepat dan tuntas artinya isi yang ada pada modul tidak membingungkan, tidak ada konsep atau uraian materi yang keliru sehingga siswa memperoleh pengetahuan secara utuh.

Disamping itu, berdasarkan karakteristik dari modul elektronik yang dikembangkan juga telah baik. Hal ini berdasarkan panduan pengembangan modul elektronik kementrian pendidikan (Nasional, 2010) bahwa karakteristik modul elektronik yang baik itu adalah: 1) Ketepatan artinya tak ada konsep atau uraian materi yang keliru; 2) Kesesuaian dengan: a) Pengalaman yang sesuai dengan kompetensi yang dituntut mata pelajaran; b) Cakupan, dalam hal ini pengalaman belajar serta tingkat kemampuan yang diharapkan dari peserta didik; 3) Ketuntasan, artinya materi dan pengalaman belajar yang disajikan memungkinkan siswa untuk memperoleh pengetahuan secara utuh; 4) Kemuktahiran, membuat hal-hal yang terkini 
atau setidaknya tidak bertentangan dengan perkembangan terbaru; 5) Kebermaknaan, artinya materi yang disajikan berguna bagi perkembangan akademik dan profesional peserta didik, 6) Ketercernaan, artinya bahasa dan sistematika sajian jelas, mudah dipahami, dan tidak membingungkan; 7) Kemenarikan, artinya menimbulkan minat dan motivasi bagi siswa untuk mempelajari bahan ajar yang disebabkan oleh penataan kegiatan belajar yang variatif dan interaktif, penggunaan bahasa yang dialogis, serta pengemasan ilustrrasi dan penwajahan yang mendukung dan menjelaskan; 8) Kebakuan, dalam: a) Ragam bahasa Indonesia yang digunakan; b) Kaidah penulisan; c) Etika penulisan, termasuk pengutipan pendapat orang lain.

Pada aspek kesesuaian bahasa, kalimat yang digunakan pada modul elektronik sudah komunikatif, sesuai dengan kaedah bahasa Indonesia, kalimat yang digunakan juga sudah sesuai dengan tingkat perkembangan dan kemampuan intelektual siswa yang heterogen. Secara keseluruhan semua aspek yang divalidasi pada modul elektronik dapat dinyatakan sudah valid.

Aspek bentuk fisik memberikan informasi tentang kemenarikan modul elektronik yang dikembangkan sehingga menimbulkan minat dan motivasi bagi siswa untuk mempelajarinya. Keenam aspek tersebut sudah mencakup karakteristik modul elektronik yang baik, sesuai dengan panduan pengembangan modul elektronik.

\section{KESIMPULAN}

Berdasarkan hasil analisis data validasi untuk mengetahui kevaliditan modul elektronik fisika berbasis konstruktivisme yang telah dikembangkan, disimpulkan bahwa modul elektronik fisika berbasis konstruktivisme untuk kelas X SMA pada materi pokok suhu dan kalor sangat valid digunakan, dengan persentase $89,08 \%$.

\section{DAFTAR PUSTAKA}

Abou El-Seoud, S., Seddiek, N., Taj-Eddin, I., Ghenghesh, P., Nosseir, A., \& El-Khouly, M. (2014). E-Learning and Students' Motivation: A Research Study on the Effect of E-Learning on Higher Education. International Journal of Emerging Technologies in Learning (IJET), 9(4), 20. https://doi.org/10.3991/ijet.v9i4.3465

Alsharif, K. (2014). How do Teachers Interpret the Term 'Constructivism' as a Teaching Approach in the Riyadh Primary Schools Context? Procedia - Social and Behavioral Sciences, 141, 1009-1018. https://doi.org/10.1016/j.sbspro.2014.05.1 70

Arkorful, V., \& Abaidoo, N. A. (2014). The role of elearning, advantages and disadvantages of its adoption in higher education. International Journal of Instructional Technology and Distance Learning, 12(1), 29-43.

https://doi.org/10.3991/ijac.v3i2.1322

Auditor, E., \& Naval, D. J. (2014). Development and Validation of Tenth Grade Physics Modules Based on Selected Least Mastered Competencies. International Journal of Education and Research, 2(12), 2201-6333. Retrieved from www.ijern.com

BSNP. Standar isi untuk satuan pendidikan dasar dan menengah (2006).

Bungum, B., Henriksen, E. K., Angell, C., Tellefsen, C. W., \& Bøe, M. V. (2015). ReleQuant - 
Improving teaching and learning in quantum physics through educational design research. NorDiNa, 11(2), 153-168.

Fauzi, B., \& Muliyati, D. (2018). WEBSITE ELEARNING BERBASIS MODUL: BAHAN PEMBELAJARAN FISIKA. Wahana Pendidikan Indonesia, 3(1), 90-95.

Gaikwad, N., \& Tankhiwale, S. (2014). Interactive E-learning module in pharmacology: a pilot project at a rural medical college in India. Perspectives on Medical Education, 3(1), 1530. https://doi.org/10.1007/s40037-0130081-0

Getuno, D. M., Kiboss, J. K., Changeiywo, J. M., \& Ogola, L. B. (2015). Effects of an E-Learning Module on Students ' Attitudes in an Electronics Class. Education and Practice, 6(36), 80-86.

Hamdunah. (2015). PRAKTIKALITAS PENGEMBANGAN MODUL KONTRUKTIVISME DAN WEBSITE PADA MATERI. LEMMA, II(1), 35-42.

Hapsari, N. D., \& Widodo, A. (2016). MENINGKATKAN PENGETAHUAN DAN KETERAMPILAN METAKOGNISI SISWA MELALUI BAHAN AJAR BERBASIS KONSTRUKTIVIS-METAKOGNITIF. In Seminar nasional Pendidikan dan Saintek (pp. 591-598).

Herawati. (2015). Pengembangan modul elearning fisika berbasis captivate. Pendidikan Terbuka Dan Jarak Jauh, 16(2), 68-75.

Indonesia, S. N. R. Undang- Undang RI Nomor 20 Tahun 2003 Tentang Sistem Pendidikan Nasional. (2003).
Jazim, Anwar, R. B., \& Rahmawati, D. (2017). The Use of Mathematical Module Based on Constructivism Approach as Media to Implant the Concept of Algebra Operation. International Electronic Journal of Mathematics Education, 12(3), 579-583.

Matanluk, O., Mohammad, B., Norizah, D., Kiflee, A., \& Imbug, M. (2013). The Effectiveness of Using Teaching Module Based on Radical Constructivism toward Students Learning Process. Procedia - Social and Behavioral Sciences, 90(InCULT 2012), 607-615. https://doi.org/10.1016/j.sbspro.2013.07.1 32

Nasional, D. K. D. D. K. P. Panduan Pengembangan Modul Elektronik (2010).

Nurmayanti, F., Bakri, F., \& Budi, E. (2015). Pengembangan Modul Elektronik Fisika dengan Strategi PDEODE pada Pokok Bahasan Teori Kinetik Gas untuk Siswa Kelas XI SMA. In Simposium Nasional Inovasi dan Pembelajaran Sains (pp. 337-340).

Perdana, F. A., Sarwanto, \& Sukarmin. (2017). Pengembangan Modul Elektronik Fisika Berbasis Keterampilan Proses Sains Untuk Meningkatkan Kemampuan Berpikir Kritis dan Motivasi Belajar Siswa SMA/MA Kelas X Pada Materi Dinamika Gerak. Inkuiri, 6(3), 61-76.

Petchtone, P. (2014). The Development of Instructional Model Integrated with Thinking Skills and Knowledge Constructivism for Undergraduate Students. Procedia - Social and Behavioral Sciences, 116, 4283-4286. https://doi.org/10.1016/j.sbspro.2014.01.9 32 
Pinilih, F. W., \& Masykuri, M. (2016). Pengembangan Modul Elektronik Fisika Berbasis Saling Temas Materi Pemanasan Global untuk Siswa SMA/MA Kelas XI. Inkuiri, 5(2), 143-155.

Rufii, R. (2015). Developing Module on Constructivist Learning Strategies to Promote Students ' Independence and Performance. International Journal of Education, $\quad 7(1)$, 18-28. https://doi.org/10.5296/ije.v7i1.6675

Sabri, A. (2010). Strategi Belajar Mengajar dan Microteaching. In Ciputat: PT Ciputat Press.

Sanjaya, W. (2008). Strategi Pembelajaran Beorientasi Standar Proses Pendidikan. In Jakarta: Kencana Prenada Media Group.

Santosa, A. S. E., Santyadiputra, G. S., \& Divayana, D. G. H. (2017). PENGEMBANGAN E-MODUL BERBASIS MODEL PEMBELAJARAN PROBLEM BASED LEARNING PADA MATA PELAJARAN ADMINISTRASI JARINGAN KELAS XII TEKNIK KOMPUTER DAN. KARMAPATI, 6(1).

Serafín, Č., Dostál, J., \& Havelka, M. (2015). Inquiry-Based Instruction in the Context of Constructivism. Procedia - Social and Behavioral Sciences, 186, 592-599. https://doi.org/10.1016/j.sbspro.2015.04.0 50

Shurygin, V. Y., \& Sabirova, F. M. (2017). Particularities of blended learning implementation in teaching physics by means of LMS Moodle. Revista Espacios, Vol. 38(No 40), Pág. 39. Retrieved from http://www.revistaespacios.com/a17v38n 40/a17v38n40p39.pdf
Sudarwati, N., Umi, Qomariah, N., \& Susilowati, L. (2015). Stages in Compiling Integrated Entepreneurship Module Based on Electronic for University Students. IOSR Journal of Humanities and Social Science, 20(8), 1-6. https://doi.org/10.9790/083720850106

Sufiyah, L., \& Sumarsono, H. (2015). Pengembangan Media Pembelajaran Modul Elektronik Interaktif pada Mata Pelajaran Ekonomi untuk Kelas X Lintas Minat Ekonomi SMA Laboratorium UM Kota Malang. JPE, 8(2), 64-74.

Suyoso, \& Nurohman, S. (2014). Developing webbased electronics modules as physics learning media. Kependidikan, 44(1), 73-82.

Trianto. (2010). Mendesain Model Pembelajaran Inovatif- Progresif Konsep, Landasan, dan Implementasinya pada Kurikulum Tingkat Satuan Pendidikan (KTSP). In Jakarta: Kencana (p. 2010).

Winkel, W. . (1996). Psikologi Pengajaran. In Jakarta: Grafindo. 